\title{
Brazil: the international financial crisis and counter-cyclical policies
}

\author{
Tito Belchior Silva Moreira and \\ Fernando Antônio Ribeiro Soares
}

ABSTRACT

This article evaluates the effectiveness of the counter-cyclical measures adopted by the Brazilian government to mitigate the effects of the subprime mortgage crisis, by analysing the repercussions of monetary, fiscal and credit policies on several of the main macroeconomic aggregates. The empirical analysis showed that expansionary credit policy was decisive for increasing family consumption and aggregate output during the crisis. While expansionary monetary policy also helped increase aggregate production during that period, investment expenditure did not respond to counter-cyclical policies. 


\section{I}

\section{Introduction}

The global economy performed vigorously in the first few years of the new millennium, particularly between 2003 and 2007; and the combination of high rates of economic growth with price stability fostered a belief that governments had dominated business cycles.

Nonetheless, although this panorama reflects a period of great evolution in the world economy, the latter, and the United States economy in particular, began to show clear signs of financial fragility as from 2007. That year saw the start of a process of major destabilization of markets, particularly in the real-estate sector.

Disequilibria in the real-estate market, and asset markets generally, reflected both macroeconomic factors and features inherent to the financial market. In the United States, which served as the lightning rod of the global crisis, the high rate of "dissaving" — reflected in the exceptionally large deficits on the current account- and overly expansionary monetary policy provoked largescale financial leveraging, encouraged by deregulation of the banking sector, and the emergence of various financial innovations, including credit derivatives and uncontrolled securitization.

This process intensified, and the leveraging of firms and families grew exponentially. In 2007, asymptotic borrowing reached its limit. At the first sign of financial fragility in the banks and excessive exposure among borrowers with insufficient payment capacity, creditors called for a replenishment of collateral margin and suspended debt refinancing. This triggered a bank run, with the potential to seriously impair the liquidity of the financial system, or even render it insolvent. In those circumstances, monetary and economic authorities around the world started to implement rescue and bailout operations, the aim of which, in principle, was not to mitigate the economic slowdown but to prevent financial collapse.

The effects of the financial crisis quickly spread to the real side of the economy. Although capital markets (both equity and bank credit) served as the main crisis transmission channel deteriorating expectations also played an important role. The result was a sharp reduction in trade and capital flows worldwide; and investment decisions were put on hold, causing aggregate demand to freeze up.

The main repercussions on the Brazilian economy started to be felt in the second half of 2008, particularly in the last quarter; and they were manifested in the following way: (i) credit crunch both domestically and worldwide; (ii) wealth destruction caused by falling asset prices; (iii) worsening expectations; (iv) plummeting commodity prices; and (v) a reduction in world trade.

Although somewhat late - because, as noted above, the effects of the global crisis initially became discernible in 2007- the Brazilian government authorities started to implement a series of measures to tackle the deterioration in the economic environment - both general (or horizontal) measures and sector-specific (vertical) measures. ${ }^{1}$ The aim was to mitigate the impact of the international crisis on Brazil, by avoiding a sharp slowdown in the economy and its negative consequences for output and employment.

In that framework, counter-cyclical fiscal, credit and monetary policies were adopted; and fiscal policy lowered the rate of industrial products tax (IPI) in specific sectors of the economy Credit policy was implemented mainly through banks and public financial institutions, which made up for the lack of private credit in several sectors of the economy, including civil construction and the automotive sector. Lastly, monetary policy implemented a substantial cut in the economy's basic interest rate, which was reflected in both nominal and real rates, thereby demonstrating the predominance of the monetary dimension in the conduct of Brazilian economic policy.

This article does not discuss the origins of, or provide explanations for, the factors causing the crisis in the United States financial system and its repercussions on the world economy. Several authors have already addressed these issues, including Mohan (2009); Rose and Spiegel (2009); Taylor (2009); Kindleberger and Aliber (2009); Krugman (2009); Lopes (2009); Rogoff and Reinhart (2010); Roubini and Mihm (2010); Kacef and López-Monti (2010). The chronology of the crisis is also beyond the scope of this article, and can reviewed in Torres Filho (2008) and Torres Filho and Rodrigues

\footnotetext{
${ }^{1}$ As horizontal measures are macroeconomic they affect society as a whole. They include the reduction in the basic interest rate. Vertical measures are specific and affect certain productive sectors, such as the automotive sector or civil construction.
} 
Borça Júnior (2008). The core of this analysis consists of an evaluation of the counter-cyclical measures adopted by the Brazilian government to mitigate the effects of the crisis. An analysis is made of the repercussions of monetary, fiscal and credit policies on some of the main macroeconomic aggregates, and in certain sectors of the economy which received government incentives.
The article is structured as follows. Following this brief introduction, section II addresses a number of methodological issues, focusing on the databases; and it describes the main counter-cyclical measures adopted in Brazil. Section III constructs estimates of the effects of the counter-cyclical measures on aggregate demand and its components; and, lastly, section IV presents conclusions.

\section{II}

\section{Methodological issues and counter-cyclical measures adopted in Brazil}

The variables and respective nomenclatures (in parentheses) used in this article are as follows: Final consumption of families - $\left(\right.$ Cons $\left.^{\mathrm{fam}}\right)$; Gross domestic product at basic prices $(Y)$; Credit to the private sector $\left(\right.$ Cred $\left.^{\text {pri }}\right)$; Basic interest-rate (percentage) implemented through the Special Settlement and Custody System (SELIC) - $(R)$; Gross fixed capital formation - $(f b c f)$; Inflation rate as measured by the Extended National Consumer Price Index (IPCA) - ( $\pi$ ); Product taxes - (imp); and Real gross domestic product at market prices deflated by the general price index - domestic supply (IGP-DI) - (pib). Table A.1 in the appendix gives details of the variables used and specifies the sources and units of measurement.

The variables cited were modified to make them stationary and thus avoid spurious regressions. The variables final consumption of families, credit to the private sector and gross fixed capital formation (investment) were normalized with respect to GDP and basic prices. They were also transformed into rates of change and were renamed as $d\left(\right.$ Cons $\left._{t}{ }^{\text {fam }} / Y_{t}\right), d\left(\right.$ Cred $\left._{t}{ }^{\text {ri }} / Y_{t}\right)$ and $d\left(f b c f_{t} / Y_{t}\right)$, respectively. ${ }^{2}$

The real interest rate (ex post) was calculated as the difference between the SELIC rate and the IPCA, and denoted as $r_{t}$. The expected value of the IPCA was not used, because that series was only available from 1999 onwards when the inflation-targeting regime began. The real interest rate variable was also transformed into a rate of change and represented through $d\left(r_{t}\right)$.

The Hodrick-Prescott filter was used to calculate the output gap Hiato ${ }_{t}^{p i b}$, defined as the difference between real and potential GDP (trend). A positive value indicates excess demand, whereas a negative value signifies idle

\footnotetext{
${ }^{2}$ Assuming $\left(\right.$ Cons $_{t}$ fam $\left./ Y_{t}\right)=a_{t}$, so d $\left(\right.$ Cons $\left._{t}^{\text {fam }} / Y_{t}\right)=\left(a_{t}-a_{t-1}\right) / a_{t-1}$.
}

productive capacity. Other variables were also measured using the Hodrick-Prescott filter. The real interest rate gap Hiato ${ }_{t}^{r}$ was defined as the difference between the real interest rate and the trend. A positive (negative) value indicates a restrictive (expansionary) monetary policy.

The gap in the tax/income ratio, denoted by $\left(I M P_{t} / Y_{t}\right)$, was defined as the difference between that variable and its trend. A positive value indicates a restrictive fiscal policy. The gap in credit to the private sector in relation to income $\left(\mathrm{Cred}_{t}{ }^{\mathrm{pri}} / Y_{t}\right)$, presented as Hiato ${ }_{t}{ }^{\text {cred }}$, was defined as the difference between $\left(\mathrm{Cred}_{t}{ }^{\mathrm{pri}} / Y_{t}\right)$ and its trend. A positive value indicates an expansionary credit policy. Sector variables also were transformed into gaps and were differentiated from their respective trends.

The square of certain variables was used, including $\left.I M P_{t} / Y_{t}\right)^{2},\left(\text { Cred }_{t} / Y_{t}\right)^{2}$ and $\left(I P I_{t} / P_{t}\right)^{2}$, for the purpose of verifying the existence of a non-linear relation between those variables and the dependent variable. Two dummy variables were also introduced. The dummy variable $D 1$, spanning the first quarter of 1991 to the second quarter of 1994, distinguishes the period prior to the real plan - characterized by inflationary instability - from the ensuing period in which inflation was brought under control. The second dummy variable, $D 2$, is used to determine the period of the subprime mortgage crisis which spans the first quarter of 2007 to the first quarter of $2010 .^{3}$

The next subsection analyses the effectiveness of the counter-cyclical measures implemented by the government during the subprime mortgage crisis. For

\footnotetext{
${ }^{3}$ Dummy variable $D 1$ takes the following values: January 1991 to February $1994=1$, otherwise $=0$. dummy variable $D 2$, takes the value 1 in the period January 2007 to January 2010, otherwise $=0$.
} 
that purpose, empirical tests were performed using the following procedures: (i) checks were made to verify whether the variables used in the econometric models are stationary, to avoid the presence of spurious regressions; (ii) once the stationarity of the series has been confirmed through unit root tests - augmented Dickey-Fuller and Phillips-Perron tests- ordinary least squares (OLS) equations are estimated; (iii) the residuals are analysed using a correlogram, and errors are adjusted using the Jarque-Bera method with the aim of turning the stochastic term into a white noise process; and (iv) the results of the estimated equations are then interpreted in the light of the signs and significance of the estimated parameters.

\section{Counter-cyclical measures in Brazil}

Since the deepening of the global financial crisis, the federal government has adopted various measures to contain the effects of the international turbulence on the Brazilian economy. In September 2008, steps were taken to address the major imbalances on the financial market through actions such as dollar auctions held by the Central Bank of Brazil. In other words, large-scale capital flight caused a substantial depreciation, which was alleviated by central bank dollar sales. In addition, new credit lines were created, and financing limits were raised, in an attempt to guarantee the continuity of the country's economic activity. Credit lines were also created for consumption, decrees were signed to guarantee the structure of the banking sector, and the rules for enforcing compulsory deposits were altered.

During the crisis, the Brazilian government adopted counter-cyclical economic policies that went beyond specific measures to alleviate the impact on specific sectors. Monetary and credit policy included a reduction in compulsory bank reserves, cuts in the basic annual interest rate calculated each day by the Special Settlement and Custody System (SELIC), and an increase in the supply of credit by public banks. Those measures aimed to alleviate the negative effects of the crisis on investment and consumption, through lower interest rates and easier credit. Fiscal policy included cuts in certain taxes and a lower primary surplus target.

The aim of both fiscal and monetary policies was to change pessimistic expectations and reduce their negative effect on consumption and investment, and lastly to avert a greater deterioration in the level of output and higher unemployment. In this framework, it was hoped that in 2010 the policies would ensure the continuity of economic recovery and fully reverse the minor recession of 2009 , as was subsequently confirmed.
The next subsection provides details of the most important counter-cyclical measures used to tackle the crisis and their chronology. ${ }^{4}$ The measures are listed according to their month of implementation.

\section{September 2008}

(i) 19 September 2008: Four days after the collapse of Lehman Brothers, which was considered decisive in magnifying the crisis to global proportions, the Brazilian exchange rate depreciated by $5 \%$. To contain the depreciation, or, following Dornbusch (1976), avoid exchange-rate overshooting, the Central Bank of Brazil auctioned US\$500 million;

(ii) 24 September 2008: The Central Bank of Brazil issued Circular No. 3.405 increasing from $\mathrm{R} \$ 100$ million (100 million reais) to $\mathrm{R} \$ 300$ million the amount that financial institutions are required to deduct from the calculation of additional reserve requirement on demand deposits, time deposits and saving deposits. It also postponed the collection of compulsory bank deposits on financial leasing operations; and the date for the entry into force of the $25 \%$ reserve ratio on deposits received was postponed from 16 January to 13 March 2009;

\section{October 2008}

(iii) 1 October 2008: Banco do Brasil, S.A. announced credits amounting to $\mathrm{R} \$ 5$ million to finance the agriculture sector;

(iv) 2 October 2008: The Central Bank of Brazil allowed banks to reduce compulsory reserve requirements by up to $40 \%$, provided they purchased credit operations from other financial institutions. The aim, in this case, was to allow for the transfer of portfolios of banks facing liquidity problems;

(v) 6 October 2008: The Office of the President of the Republic published Provisional Measure No. 442, granting the Central Bank of Brazil powers to purchase the portfolios of banks based in the country. In this case, the objective was to show bank customers that the government was determined to defend deposits and thus avoid bank runs;

(vi) 8 October 2008: Given the sharp exchange rate depreciation of over $9 \%$, the Central Bank of Brazil made dollar sales on the spot market;

(vii) 9 October 2008: In the same week in which the provisional measure was published allowing the Central Bank of Brazil to buy portfolios from banks

\footnotetext{
${ }^{4}$ For further details on the measures adopted and an analysis of the most relevant ones, see Relatório das Contas do Governo, exercício de 2009 [Report on government accounts, fiscal year 2009], on the website of the Federal Audit Department (Tribunal de Contas da União).
} 
with liquidity problems, the National Monetary Council (CMN) issued regulations on this;

(viii) 13 October 2008: The Central Bank of Brazil raised the limit on the deduction of bank compulsory reserves to increase liquidity in the economy;

(ix) 14 October 2008: The Central Bank of Brazil reduced from $45 \%$ to $42 \%$ the percentage collection of compulsory reserves and the compulsory special reserve on demand deposits;

(x) 16 October 2008: The Central Bank of Brazil allowed asset sales between banks to increase cash liquidity;

(xi) 21 October 2008: Provisional Measure No. 443 was published, authorizing Banco do Brasil and the Federal Savings Bank (Caixa Econômica Federal $\mathrm{CEF}$ ) to set up subsidiaries and take shares in financial institutions based in Brazil;

(xii) 22 October 2008: The Tax on Financial Operations (IOF) was lowered to zero in exchange settlement operations associated with foreign investment inflows in Brazil, with the aim of stimulating capital inflows and, thus, reduce pressure on the foreignexchange market;

(xiii) 27 October 2008: Banks that had paid 60 monthly contributions to the Credit Guarantee Fund, could now reduce the respective amount from the compulsory demand deposit. The aim of this was to increase liquidity in the economy;

(xiv) 30 October 2008: The Federal Reserve System (the United States central bank) and the Central Bank of Brazil set up a financial swap facility for US\$30 billion, maturing on 30 April 2009. The aim was to improve liquidity in the international financial system;

(xv) 30 October 2008: The Central Bank of Brazil altered remuneration of the compulsory time deposit with the aim of increasing credit in the market;

\section{November 2008}

(xvi) 4 November 2008: The Central Bank of Brazil issued rules governing dollar auctions to finance exports. Given the aforementioned freezing of the international commercial credit market, the central bank took steps to provide a credit to exporters;

(xvii) 6 November 2008: The federal government released credits for a total of US\$6.9 billion for small and medium-sized enterprises and for the automotive sector;

(xviii) 11 November 2008: The Government of the State of São Paulo set up a credit line of $\mathrm{R} \$ 4$ billion for the automotive sector. On the same day, the CEF increased the limit for loans to purchase construction materials from $\mathrm{R} \$ 7,000$ reais to $\mathrm{R} \$ 25,000$; (xix) 12 November 2008: The CEF released a credit line for private individuals amounting to $\mathrm{R} \$ 2$ billion, intended for the purchase of electrical appliances, electronic equipment, furniture and construction materials;

(xx) 13 November 2008: As from 1 December 2008, the additional reserve requirement on time, demand, and saving deposits would be made through government bonds. This expanded the financing capacity of the public sector;

(xxi) 14 November 2008: The Office of the President of the Republic published Provisional Measure No. 452 447, extending for 10 days the deadline for collecting the on industrial products tax (IPI), tax withheld at source and the social security contribution. The collection period for the Social Integration Programme and the Contribution to the Financing of the Social Security System (PIS/COFINS) were also extended by five days. The changing the tax collection date was expected to contribute $\mathrm{R} \$ 21$ million to enterprise cash flows;

(xxii) 21 November 2008: A decree was published lowering the IOF rate from $3.38 \%$ to $0.38 \%$, for the financing of motorcycles, motor scooters, and mopeds;

\section{December 2008}

(xxiii) 11 December 2008: Decree No. 6.687 reduced the IPI rates on the sale of vehicles and trucks. This measure would be enforced from 15 December 2008 to 31 March 2009;

(xxiv) 11 December 2008: Decree No. 6.691 lowered the IOF rate applicable to credit operations with private individuals;

(xxv) 15 December 2008: The Federal government, through Provisional Measure No. 451, announced the change in rates for personal income-tax (IRPF); and

\section{January 2009}

(xxvi) 22 January 2009: Provisional Measure No. 453 was issued, constituting an additional source of funding for the National Bank for Economic and Social Development (BNDES), amounting to R $\$ 100$ billion, with the aim of increasing availability of long-term credit.

Counter-cyclical measures continued to be implemented in 2009, including a reduction in the IPI rates applied to white-line electrical appliances. Capital goods and construction materials were also temporarily exempted from IPI. Other measures were adopted with respect to credit, including a reduction in the longterm interest rate. In addition, the government adopted a combination of investment and income-generating policies. The first included the creation of the Accelerated Growth Programme (PAC II), while in the social area it 
is important to mention the civil construction policy, represented by the Minha Casa Minha Vida [My home, my life] programme, and the extra resources made available to the population by increasing the amount of the subsidy paid by the Bolsa Familia programme and raising the minimum wage.

Although the details of measures to combat the crisis and their respective chronology may seem mundane, the aim of this article is to analyse the counter-cyclical measures and their effectiveness in reducing the adverse effects of the international crisis. For that reason, the long list presented above is considered relevant for visualizing the path taken by the government in that endeavour.
In brief, the policies applied by the government were implemented in various areas. Firstly, the aim was to maintain the external sector by extending credit to exporters, since traditional credit lines were frozen. With regard to the financial system, measures were taken to maintain the liquidity insolvency of the banks, while signalling to the markets the government's serious intention to prevent a potential bank run. In terms of reviving the economy, an expansionary monetary policy was implemented through cuts in basic interest rates and a major credit expansion. Fiscal policy also had expansionary effects by granting a number of tax exemptions.

\section{III}

\section{The effectiveness of counter-cyclical measures in Brazil: aggregate analysis}

This section discusses one of the fundamental aspects of this research: the effectiveness of the counter-cyclical policies implemented by the Brazilian authorities in late 2008 and early 2009. To this end, a review is made of economic policy measures, to establish which in fact proved appropriate in combating the economic slowdown and rise in unemployment, and avoiding the effects of the deepening international crisis in Brazil. An analysis is then made of aggregate economic policy measures aimed at producing effects on the economy as a whole.

After that, empirical evidence is presented on the effects of the counter-cyclical policies in the Brazilian economy - in particular, the effects of fiscal, monetary and credit policies on the family consumption, aggregate investment, and the output gap.

\section{Counter-cyclical effects of monetary and credit policies on family consumption}

The following paragraphs evaluate the repercussions of credit extended to the private sector on aggregate family consumption. This analysis is based on the Keynesian consumption function, which is extended to incorporate the credit variable, such that:

$$
\text { Cons }_{t}^{\text {fam }}=\beta_{0}+\beta_{1} Y_{t}+\beta_{2} \text { Cred }_{t}^{\text {pri }}
$$

Normalizing equation (1) with respect to aggregate income, gives the following function:

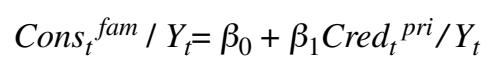

A positive sign is expected for the $\beta_{1}$ credit coefficient. In other words, given an increase in the ratio between the volume of lending to the private sector and aggregate income, family consumption is expected to increase as a proportion of the same aggregate income.

To eliminate the possibility of spurious regression, the variables defined in equation (2) were expressed as rates of change. Table A.2 in the appendix shows that the family consumption and private sector credit variables - both in relation to income - are stationary, so the unit root hypotheses is rejected. Equation (2) can then be rewritten in stochastic form. In addition, two variables are added, an interactive variable and the dummy variable $D 1$.

$$
\begin{gathered}
d\left(\text { Cons }_{t} \text { fam }_{\text {fa }}\right)=\beta_{0}+\beta_{1}{ }^{*} d\left(\text { Cred }_{t}{ }^{\text {pri }} / Y_{t}\right)+ \\
\beta_{2}{ }^{*} d\left(\text { Cred }_{t}{ }^{\text {pri }} / Y_{t}\right)^{*} D 2+\beta_{3}{ }^{*} D 1+u_{t}
\end{gathered}
$$

The variable $D 1$ is used to capture effects prior to the real plan, which, as has been noted, correspond to a period of uncontrolled inflation. In contrast, the interactive variable $d\left(\mathrm{Cred}_{t}{ }^{\text {pri }} / \mathrm{Y}_{t}\right)^{*} \mathrm{D} 2$, is used to evaluate the effects of the change in the credit/income ratio since the subprime mortgage crisis, in other words from the first quarter of 2007 until the first quarter of 2010 (dummy D2), on the dependent variable $d\left(\right.$ Cons $\left._{t}^{f a m} / Y_{t}\right)$. 
The estimated parameter $\hat{\beta}_{1}$ will indicate the effect of the explanatory variable $d\left(\right.$ Cred $\left._{t}^{p r i} / Y_{t}\right)$ on the dependent variable $d\left(\right.$ Cons $\left._{t}{ }^{\text {fam }} / Y_{t}\right)$ throughout the period. Moreover, the sum of the estimated parameters $\hat{\beta}_{1}$ and $\hat{\beta}_{2}$ will represent the effect of the variable $d\left(\right.$ Cred $_{t}$ pri $^{\prime}$ $\left.Y_{t}\right)$ on the variable $d\left(\mathrm{Cons}_{t} \mathrm{fam} / Y_{t}\right)$ in the period between January 2007 and January 2010. The sum of the estimated parameters $\left(\hat{\beta}_{1}+\hat{\beta}_{2}\right)$ will reveal the effect of the variable of interest -in this case the joint effect of the variables $d\left(\right.$ Cred $\left._{t}{ }^{\text {rri }} / Y_{t}\right)$ and $d\left(\text { Cred }_{t}{ }^{\text {pri }} / Y_{t}\right)^{*} D 2$ - on the dependent variable $d\left(\mathrm{Cons}_{t} \mathrm{fam}_{\mathrm{F}} \mathrm{Y}_{t}\right)$ during the crisis period. In this way, the repercussions of the counter-cyclical policies implemented by the government during the financial crisis can be evaluated. This procedure will also be applied to the other estimations.

The results shown in table 1 represent the estimation of equation (3), which is basically used to analyse how credit, in its various versions, affected family consumption. It can firstly be seen that all of the estimated parameters are statistically significant at the $95 \%$ confidence level, except for the parameter representing the intercept $\left(\hat{\beta}_{0}\right)$.

According to the statistics shown in table 1, a 10\% increase in the credit variable, specifically through $d\left(\mathrm{Cred}^{\mathrm{pri}} / \mathrm{Y}\right)$, is associated with an increase of about $6.1 \%$ in family consumption, $d\left(\right.$ Cons $\left._{t}{ }^{\text {fam }} / Y_{t}\right)$, In other words, credit really does have an effect on aggregate demand through consumption in the period analysed.

The sum of the estimated parameters $\hat{\beta}_{1}$ and $\hat{\beta}_{2}$ is 0.095 , which means that a $10 \%$ increase in credit, $d\left(\mathrm{Cred}^{\mathrm{pri}} / \mathrm{Y}\right)$, elicits an increase of about $1 \%$ in family consumption, $d\left(\right.$ Cons $\left._{t}{ }^{\text {fam }} / Y_{t}\right)$ in the crisis period. This shows that the counter-cyclical credit policy implemented by the government to combat the negative effects of the external imbalances had a positive effect on family consumption.

As expected, the dummy variable $D 1$ had a negative effect on the family consumption variable, which suggests that the price instability period prior to the real plan reduced family purchasing power and, consequently, had a negative effect on families' final consumption. Looking beyond the effects of the 2008 and 2009 financial crisis, the result of the dummy variable $D 1$ is quite interesting, since it clearly shows that the loss of control over prices acted as an inflation tax on society, with a negative effect on final consumption. ${ }^{5}$

Continuing the analysis of the effects of the countercyclical monetary and credit policies, equation (3) was modified to incorporate the real interest rate, as shown in equation (4)

$$
\begin{gathered}
d\left(\text { Cons }_{t}{ }^{\text {fam }} / Y_{t}\right)=\beta_{0}+\beta_{1}{ }^{*} d\left(\text { Cred }_{t}{ }^{\text {pri }} / Y_{t}\right)+ \\
\beta_{2}{ }^{*} d\left(\text { Cred }_{t}{ }^{\text {pri }} / Y_{t}\right)^{*} D 2+\beta_{3}{ }^{*} d\left(r_{t-1}\right)+ \\
\beta_{4}{ }^{*} d\left(r_{t-1}\right)^{*} D 2+u_{t}
\end{gathered}
$$

\footnotetext{
${ }^{5}$ The regression was adjusted on the basis of an autoregressive moving average (ARMA) model, so that the residuals were turned into a white noise process. The estimated coefficients of $\mathrm{AR}(1), \mathrm{AR}(3), \mathrm{MA}(2)$, $\mathrm{MA}(3)$ and $\mathrm{MA}(4)$ are statistically significant at the 5\% level. This aims to reaffirm the validity of the regression. The correlogram of the residuals was verified and revealed a white noise process.
}

TABLE 1

\begin{tabular}{|c|c|c|c|c|}
\hline Variable & Coefficient & Standard deviation & Student t-statistic & P-statistic \\
\hline Intercept & $<0.001$ & 0.004 & 0.275 & 0.784 \\
\hline$d\left(\mathrm{Cred}^{\mathrm{pri}} / \mathrm{Y}\right)$ & 0.608 & 0.049 & 12.272 & $<0.001$ \\
\hline$d\left(\mathrm{Cred}^{\text {pri }} / Y\right)^{*} \mathrm{D} 2$ & -0.513 & 0.181 & -2.839 & 0.006 \\
\hline D1 & -0.023 & 0.010 & -2.261 & 0.027 \\
\hline $\mathrm{AR}(1)$ & -0.333 & 0.087 & -3.820 & $<0.001$ \\
\hline $\mathrm{AR}(3)$ & -0.644 & 0.089 & -7.215 & $<0.001$ \\
\hline $\mathrm{MA}(2)$ & -0.226 & 0.094 & -2.417 & 0.018 \\
\hline MA(3) & 0.726 & 0.086 & 8.416 & $<0.001$ \\
\hline $\mathrm{MA}(4)$ & 0.428 & 0.077 & 5.540 & $<0.001$ \\
\hline $\mathrm{R}^{2}$ & 0.787 & & F-statistic & 29.648 \\
\hline Durbin-Watson (DW) & 1.903 & & $\begin{array}{l}\text { P-statistic } \\
\text { (F-statistic) }\end{array}$ & $<0.001$ \\
\hline
\end{tabular}

Estimation of equation (3): Effect of credit on family consumption (January 1991-January 2010)

Source: Prepared by the authors.

Note: Equation estimated by ordinary least squares (oLs). 
To simplify, throughout this article variables expressed as rates (such as the rate of change of the credit/ income ratio, and the rate of change of the real interest rate) are referred to as credit and real interest rate. The results of the estimation of equation (4) are shown in table 2.

The statistics set out in table 2 show that the estimated parameters $\hat{\beta}_{1}$ and $\hat{\beta}_{3}$ are statistically significant at the 95\% confidence level. Moreover, the parameter $\hat{\beta}_{2}$ is marginally significant at the $10 \%$ significance level. These results suggest that a $10 \%$ increase in the credit variable is associated with an increase of around 3.5\% in family's final consumption, the sum of the estimated parameters $\hat{\beta}_{1}$ and $\hat{\beta}_{2}$ is 0.155 , which means that a $10 \%$ increase in credit produces a $1.5 \%$ increase in family consumption during the crisis period.

The estimated parameters strengthen the hypothesis that the credit policy implemented to mitigate the effects of the global crisis in Brazil was effective, because it had a positive effect on family consumption. These estimations corroborate those shown in table $1 .^{6}$

It can also be seen that a $1 \%$ reduction in the variable $d\left(r_{t-1}\right)$, representing the real interest rate, involves an increase of $0.005 \%$ in final family consumption during the period analysed. The estimated coefficient of the interactive variable $d\left(r_{t-1}\right)^{*} D 2$ is statistically zero at -0.005 , which implies that the change in the real interest rate during the crisis period did not affect the change

${ }^{6}$ The inclusion of the real interest rate resulted in a loss of significance for the dummy variable $D 1$, which refers to the pre-real plan inflationary period, and consequently was rejected from the model. in family consumption. An explanation for that result could be that, when purchasing durable consumer goods, consumers use the financing term as a control variable rather than the interest rate, ${ }^{7}$ to ensure that installments are compatible with the availability of income. ${ }^{8}$

\section{Counter-cyclical effects of monetary and credit policies on gross fixed capital formation (investments)}

This subsection evaluates the repercussions of the real interest rate and lending to the private sector on gross fixed capital formation (FBCF). The analysis was based on the Keynesian investment function, ${ }^{9}$ which is expanded to incorporate the credit variable.

$$
F B C F_{t}=\beta_{0}+\beta_{1}{ }^{*} Y_{t}+\beta_{2}{ }^{*} r_{t}+\beta_{3}{ }^{*} \operatorname{Cred}_{t}{ }^{p r i}
$$

Normalizing equation (5) through aggregate income gives the following function:

$$
F B C F_{t} / Y_{t}=\beta_{0}+\beta_{1}^{*} r_{t}+\beta_{2}^{*}\left(\operatorname{Cred}_{t}{ }^{\text {pri }} / Y_{t}\right)
$$

\footnotetext{
${ }^{7}$ The basic issue for the consumer would not be the interest charges paid but adapting the loan to his or her budget.

${ }^{8}$ In this case, the regression was also adjusted on the basis of a ARMA process, so that the residuals became white noise. The estimated parameters $\mathrm{AR}(1), \mathrm{AR}(4)$ and $\mathrm{MA}(2)$ are statistically significant at the $1 \%$ level. Lastly, the correlogram of the residuals verified the white noise process.

${ }^{9}$ A complete version of the Keynesian investment function would require the inclusion of a variable representing business expectations.
}

Estimation of equation (4): Effect of credit and the real interest rate on family consumption

\begin{tabular}{|c|c|c|c|c|}
\hline Variable & Coefficient & Standard deviation & Student t-statistic & P-statistic \\
\hline Intercept & -0.0005 & 0.002 & -0.222 & 0.824 \\
\hline$d\left(\right.$ Cred $\left.^{p r i} / Y\right)$ & 0.355 & 0.066 & 5.397 & $<0.001$ \\
\hline$d\left(\mathrm{Cred}^{p r i} / Y\right)^{*} \mathrm{D} 2$ & -0.200 & 0.117 & -1.709 & 0.087 \\
\hline$d\left(r_{t-1}\right)$ & -0.005 & 0.002 & -2.089 & 0.037 \\
\hline$d\left(r_{t-1}\right)^{*} D 2$ & 0.006 & 0.007 & 0.861 & 0.389 \\
\hline $\mathrm{AR}(1)$ & -0.339 & 0.076 & -4.444 & $<0.001$ \\
\hline $\operatorname{AR}(4)$ & 0.605 & 0.068 & 8.819 & $<0.001$ \\
\hline MA(2) & -0.353 & 0.100 & -3.517 & $<0.001$ \\
\hline $\mathrm{R}^{2}$ & 0.710 & & F-statistic & 14.689 \\
\hline Durbin-Watson (DW) & 2.103 & & $\begin{array}{l}\text { P-statistic } \\
\text { (F-statistic) }\end{array}$ & $<0.001$ \\
\hline
\end{tabular}

(January 1991-January 2010)

Source: Prepared by the authors.

Note: Equation estimated by ordinary least squares (oLs). 
The coefficients $\hat{\beta}_{1}$ and $\hat{\beta}_{2}$ are expected to be negative and positive, respectively. In other words, a reduction in real interest rates is expected to stimulate investment, which would also receive incentives as a result of the credit expansion. Transforming the variables into rates of change gives the equation (7). ${ }^{10}$

$$
\begin{gathered}
d\left(F B C F_{t} / Y_{t}\right)=\beta_{0}+\beta_{1}{ }^{*} d\left(r_{t}\right)+\beta_{2}{ }^{*} d\left(\operatorname{Cred}_{t}^{\text {pri }} / Y_{t}\right) \\
+\beta_{3}{ }^{*} d\left(\text { Cred }_{t} \text { pri } / Y_{t}\right) * D 2+\beta_{4}{ }^{*} d\left(r_{t}\right)^{*} D 2+u_{t}
\end{gathered}
$$

The results for equation (7) are set out in table 3 and show that the estimated parameters $\hat{\beta}_{0}, \hat{\beta}_{2}, \hat{\beta}_{3}$ and $\hat{\beta}_{4}$ are not statistically significant at the $95 \%$ confidence level. These results are revealing, since they show that the change in the real interest rate did not have effects on the variation of FBCF (investment) in the analysis covering the whole period. This may suggest two consequences: (i) the key factor in the level of investment is entrepreneurial expectations; and (ii) the interest rate which in fact is used to finance a substantial part of private sector investment, is not the economy's basic interest rate or the SELIC. ${ }^{11}$

Another interesting result concerns the statistically zero effect of changes in credit policy during the crisis period. Here again, this result could be related to the pessimistic climate among the business community. Thus, negative expectations for the future of the economy

${ }^{10}$ The aim of this is to eliminate risks of spurious regression. The stationarity of the variables can be seen in table A. 2 of the appendix.

11 The relevant rates would be those of the BNDES and other government lending institutions. would make credit policy less effective in stimulating new investments during the crisis period. In the climate of pessimism caused by the world recession and, to a lesser extent the domestic one, entrepreneurs opted to postpone investments.

On the other hand, the coefficient $\hat{\beta}_{1}$ is statistically significant at the $95 \%$ confidence level, so credit can be seen as a decisive factor for investments. This estimation can be interpreted as follows: a $10 \%$ increase in credit generates an increase in investment of about $4 \%$ over the whole period. As that parameter was not altered in response to an expansionary credit policy in the crisis period, $\hat{\beta}_{1}+\hat{\beta}_{2}=0.434+0=0.434 .^{12}$

\section{Counter-cyclical effects of fiscal policy on output}

Having evaluated the effects of credit operations and the real interest rate on family consumption and FBCF (investments), the analysis is now extended to measure not only the effects of monetary and credit policy on output, but also those of fiscal policy. The estimated equation is shown below.

$$
\begin{aligned}
& \text { Hiato }^{\text {pib }}=\beta_{0}+\beta_{1}{ }^{*} \text { Hiato }_{t-1}^{r}+\beta_{2}{ }^{*} \text { Hiato }_{t-1}^{r}{ }^{*} D 2 \\
& +\beta_{3}{ }^{*} \text { Hiato }_{t-1}^{i m p / Y}+\beta_{4}{ }^{*} \text { Hiato }_{t-1}^{i m p / Y^{*}} D 2+ \\
& \beta_{5}{ }^{*} \text { Hiato }_{t-1}^{\text {cred } / P}+\beta_{6}{ }^{*} \text { Hiato o }_{t-1}^{\text {cred } / P^{*}} D 2+\beta_{7}{ }^{*}(I M P / Y)^{2}+u_{t}
\end{aligned}
$$

\footnotetext{
12 The estimated regression was adjusted on the basis of a MA(24) process, so that the residuals displayed a white noise process. The validity of the estimated regression was thus guaranteed.
}

Estimation of equation (7): Effect of credit and the real interest rate on gross fixed capital formation (January 1991-January 2010)

\begin{tabular}{lcccr}
\hline Variable & Coefficient & Standard deviation & Student t-statistic & P-statistic \\
\hline Intercept & 0.004 & 0.007 & 0.530 & 0.598 \\
$d\left(\right.$ Cred $\left.^{\text {ri }} / Y\right)$ & 0.434 & 0.188 & 2.313 & 0.024 \\
$d\left(\text { Cred }^{p r i} / Y\right)^{*} D 2$ & -0.487 & 0.308 & -1.582 & 0.118 \\
$d(r)$ & -0.0007 & 0.003 & -0.190 & 0.849 \\
$d(r)^{*} D 2$ & -0.0002 & 0.014 & -0.011 & 0.991 \\
MA $^{2}$ (24) & 0.911 & 0.035 & 26.188 & $<0.001$ \\
$\mathrm{R}^{2}$ & 0.724 & & F-statistic & 36.789 \\
Durbin-Watson (Dw) & 1.971 & & P-statistic & $<0.001$ \\
& & & (F- statistic) & \\
\hline
\end{tabular}

Source: Prepared by the authors.

Note: Equation estimated by ordinary least squares (OLS). GFCF: gross fixed capital formation. 
Basically, equation (8) shows that the output gap, in other words the difference between actual and potential output, is affected by gaps in the interest rate and credit operations (divergence of variable from its trend) - and the tax gap. Estimations of equation (8) are shown in table 4.

The results set out in table 4 show that the estimated parameters are statistically significant at the 95\% confidence level except for the parameters $\hat{\beta}_{0}$, $\hat{\beta}_{3}, \hat{\beta}_{4}$ and $\hat{\beta}_{7}$. It can be seen that taxes, in their various specifications, did not significantly affect the output gap and therefore did not help mitigate the effects of the 2008-2009 global crisis. The estimated coefficient of the square of the tax/GDP ratio is also not statistically significant, thereby suggesting the nonexistence of a non-linear relation between the taxes/GDP ratio and the output gap.

The interest-rate coefficient has the expected negative sign, such that a $10 \%$ reduction in the lagged interest-rate variable in involves a $0.05 \%$ increase in the output gap. Another conclusion can be drawn from the fact that that result is identical to the ratio between the variation in the real interest rate and the variation in family consumption. Although the coefficient $\hat{\beta}_{1}$ is statistically different from zero, it is nonetheless very small, which reveals the low elasticity of the output gap with respect to changes in interest rates.
During the crisis period there was a larger negative effect of the real interest rate gap on the output gap. The sum of the estimated parameters $\hat{\beta}_{1}$ and $\hat{\beta}_{2}$ produces a negative result of -0.05 , which means that $10 \%$ reduction in the interest-rate in the crisis period involves a 5\% improvement in the output gap — so expansionary monetary policy had a significant effect on the recovery process in the Brazilian economy. Comparing the normal period with the crisis period, it can be seen that the power of the interest rate effect increased by $1,000 \%$, specifically in the crisis period.

The tax gap in relation to income is marginally significant at the $10 \%$ level. In this case, it can be concluded that a $10 \%$ reduction in the lagged tax variable involves an increase of about $3 \%$ in the output gap. The interactive variable Hiato ${ }_{t-1}^{i m p / Y^{*}} D 2$ is not statistically significant, however, which shows that counter-cyclical fiscal policy was not statistically significant in explaining the recovery of the Brazilian economy during the crisis period.

In relation to credit policy, the model estimated from equation (8) produced significant coefficients. Specifically, the estimated coefficients for credit — both covering the whole period analysed and the period subsequent to the sub prime mortgage crisis- statistically affect the output gap. Nonetheless, the values are close to 0 , which suggests that credit, in the specification given by

Estimation of equation (8): Effects of the interest rate gap, credit operations and tax gap on the output gap

(January 1991-January 2010)

\begin{tabular}{|c|c|c|c|c|}
\hline Variable & Coefficient & Standard deviation & Student t-statistic & P-statistic \\
\hline Intercept & 0.093 & 0.064 & 1.462 & 0.149 \\
\hline Hiato $_{t-1}^{r}$ & -0.005 & 0.003 & -2.009 & 0.049 \\
\hline Hiato $_{t-1}^{r}{ }^{*} D 2$ & -0.045 & 0.017 & -2.547 & 0.013 \\
\hline Hiato $o_{t-1}^{i m p / Y}$ & -0.305 & 0.169 & -1.804 & 0.076 \\
\hline Hiato $_{t-1}^{i m p} / Y^{*} D 2$ & -0.289 & 0.372 & -0.777 & 0.440 \\
\hline Hiato ${ }_{t-1}^{\text {cred } / P}$ & $2.48 \mathrm{E}-07$ & $8.78 \mathrm{E}-08$ & 2.828 & 0.006 \\
\hline Hiato ${ }_{t-1}^{\text {cred } / P^{*}} D 2$ & $-2.19 \mathrm{E}-07$ & $1.09 \mathrm{E}-07$ & -2.007 & 0.049 \\
\hline$\left(I M P_{t} / Y_{t}\right)^{2}$ & -3.103961 & 2.206929 & -1.406 & 0.164 \\
\hline $\mathrm{AR}(4)$ & 0.410 & 0.112 & 3.656 & $<0.001$ \\
\hline $\mathrm{R}^{2}$ & 0.542 & & F-statistic & 9.314 \\
\hline DW & 1.511 & & $\begin{array}{l}\text { P-statistic } \\
\text { (F- statistic) }\end{array}$ & $<0.001$ \\
\hline
\end{tabular}

Source: Prepared by the authors.

Note: Equation estimated by ordinary least squares (oLs). 
equation (8), apparently had little effect on the output gap. Similarly, the sum of the parameters $\hat{\beta}_{5}$ and $\hat{\beta}_{6}$ produced a significant statistic with the expected sign (positive), but a value close to 0 . Nonetheless, as the values of the credit variable are expressed in billions of reais, the repercussion of a very small value, but statistically different from 0 , on a very large value, is not negligible. Consequently, based on the model specified by equation (8), it can be stated that credit produced a considerable effect on the output gap. ${ }^{13}$

${ }^{13}$ Here again the regression was adjusted. An AR(4) was estimated, which was statistically significant at the $1 \%$ level. The residuals of the adjusted regression thus displayed a white noise process.
Accordingly, based on the results summarized in table 5, it can be inferred that: (i) family consumption responded positively to the expansionary credit policy; (ii) FBCF (investment) was not sensitive to expansionary monetary and credit policies; and (iii) output was sensitive to the expansionary monetary policy implemented through a cut in real interest rates and it responded positively to the credit expansion. Lastly, the expansionary fiscal policy (which involved tax cuts) did not have the effect on output. This is corroborated by evaluating the government's intertemporal constraint. Basically, forgoing revenue or increasing current expenditure should be offset in the near future with restrictive measures that ensure the solvency of the public accounts.

TABLE 5

Summary of the results of counter-cyclical policies

\begin{tabular}{lccc}
\hline Dependent variable & Monetary policy & Credit policy & Fiscal policy \\
\hline Family consumption & Ineffective & Effective & Not evaluated \\
Investment & Ineffective & Ineffective & Not evaluated \\
Output & Effective & Effective & Ineffective \\
\hline
\end{tabular}

Source: Prepared by the authors.

\section{IV}

\section{Conclusions}

The empirical analysis showed that the expansionary credit policy played a key role in boosting family consumption and aggregate output during the crisis. Expansionary monetary policy was also important in increasing aggregate output in the same period. In contrast, investment expenditure did not prove sensitive to the counter-cyclical monetary, credit and fiscal policies. This result can be explained by the high level of uncertainty and negative expectations regarding the future of the economy, which were possibly decisive for entrepreneurs to adopt a more cautious and conservative stance, suspending a large proportion of ongoing investments and cancelling new projects. Thus, from the aggregate-demand standpoint, monetary and credit policies played an important role in the recovery of the Brazilian economy, whereas, fiscal policy proved ineffective in reviving business activity in the country.

It is worth drawing attention to number of points relating to the cost-benefit ratio of the counter-cyclical policies implemented. The empirical results broadly show that, unlike monetary and credit policies, fiscal policy was not a key player in the recovery of economic activity. Apart from possibly providing a minimum benefit, fiscal policy involved a high cost in the form of additional public debt resulting from a larger nominal fiscal deficit. It will be worth studying the consequences of the use of expansionary fiscal policies in future research, since the empirical analysis shows that short-term benefit was minimal, while the cost, even in the short run, was not negligible. Taking a long-term view, the increase in expenditure, particularly permanent expenses (wages and social security, among others), and the reduction in revenue, will require additional measures to restore the fiscal adjustment, and this could reduce resources available for private investment.

(Original: Portuguese) 
APPENDIX

TABLE A. 1

Description of aggregate variables

\begin{tabular}{|c|c|c|c|}
\hline Variable & Acronym & Unit of measurement & Source \\
\hline Final family consumption & Cons ${ }^{\text {fam }}$ & $\mathrm{R} \$$ million & IPEA \\
\hline GDP at basic prices & $Y$ & $\mathrm{R} \$$ million & IPEA \\
\hline $\begin{array}{l}\text { Basic interest rate implemented through the Special } \\
\text { Settlement and Custody System (SELIC) }\end{array}$ & $R$ & Percentages & IPEA \\
\hline Gross fixed capital formation & $f b c f$ & $\mathrm{R} \$$ million & IPEA \\
\hline $\begin{array}{l}\text { GDP at market prices deflated by the general price index - } \\
\text { domestic supply (IGP-DI). }\end{array}$ & pib & $\mathrm{R} \$$ million & IPEA \\
\hline $\begin{array}{l}\text { Inflation rate as measured by the Extended National } \\
\text { Consumer Price Index (IPCA) }\end{array}$ & $\pi$ & Percentages & IPEA \\
\hline Lending to the private sector & Cred $^{\text {pri }}$ & $\mathrm{R} \$$ million & IPEA \\
\hline Product taxes & imp & Chained index (ave. $1995=100)$ & IPEA \\
\hline
\end{tabular}

Source: Prepared by the authors.

Note: Institute of Applied Economic Research (IPEA).

TABLE A.2

Unit root test

(January 1991-January 2010)

\begin{tabular}{|c|c|c|c|c|c|c|}
\hline Variables & $\begin{array}{l}\text { Augmented Dickey- } \\
\text { Fuller test (ADF) (SIC) }\end{array}$ & $\begin{array}{l}\mathrm{ADF} \\
\text { (SIC) }\end{array}$ & $\begin{array}{l}\mathrm{ADF} \\
(\mathrm{SIC})\end{array}$ & $\begin{array}{l}\text { Phillips-Perron } \\
\text { test }\end{array}$ & $\begin{array}{l}\text { Phillips-Perron } \\
\text { test }\end{array}$ & $\begin{array}{c}\text { Phillips-Perron } \\
\text { test }\end{array}$ \\
\hline & Critical value $5 \%$ & $\begin{array}{l}\text { Student } \\
\text { t-statistic }\end{array}$ & P-statistic & $\begin{array}{c}\text { Critical value } \\
5 \%\end{array}$ & $\begin{array}{l}\text { Student } \\
\text { t-statistic }\end{array}$ & P-statistic \\
\hline$(\mathrm{imp} / Y)^{2}$ & $-3.471 * *$ & -2.861 & 0.181 & $-3.470 * *$ & -4.614 & 0.002 \\
\hline$d(r)$ & $-1.946^{*}$ & -6.563 & $<0.001$ & $-1.945^{*}$ & -9.206 & $<0.001$ \\
\hline$d(f b c f / Y)$ & $-1.945^{*}$ & -8.511 & $<0.001$ & $-1.945^{*}$ & -10.754 & $<0.001$ \\
\hline$d\left(\right.$ Cons $_{t}$ fam $\left._{/} Y_{t}\right)$ & $-1.946^{*}$ & -4.945 & $<0.001$ & $-1.945^{*}$ & -29.860 & $<0.001$ \\
\hline$d\left(\operatorname{Cred}_{t}^{\text {pri }} / Y_{t}\right)$ & $-1.945^{*}$ & -8.115 & $<0.001$ & $-1.945^{*}$ & -8.143 & $<0.001$ \\
\hline Hiato $^{\text {cred }}$ & $-1.945^{*}$ & -3.203 & 0.002 & $-1.945^{*}$ & -2.636 & 0.009 \\
\hline Hiato $^{\text {pib }}$ & $-1.946^{*}$ & -2.196 & 0.028 & $-1.945^{*}$ & -5.728 & $<0.001$ \\
\hline Hiato $^{\text {imp } / Y}$ & $-1.945^{*}$ & -4.647 & $<0.001$ & $-1.945^{*}$ & -4.712 & $<0.001$ \\
\hline Hiato $^{r}$ & $-1.945^{*}$ & -8.743 & $<0.001$ & $-1.945^{*}$ & -10.310 & $<0.001$ \\
\hline
\end{tabular}

Source: Prepared by the authors.

Notes: (i) $\mathrm{H}_{0}$ : displays a unit root; (ii) One asterisk $(*)$ represents test with constant; and two asterisks (**) represents a test with a constant and trend; (iii) $d x_{t}=\left(x_{t}-x_{t-1}\right) / x_{t-1}=\left(\Delta x_{t} / x_{t-1}\right)$.

SIC: Schwartz information criterion. 


\section{Bibliography}

Central Bank of Brazil (various issues), Boletim do Banco Central do Brasil, Brasilia.

Dornbusch, Rudiger (1976), "Expectations and exchange rate dynamics", Journal of Political Economy, vol. 84, No. 6, Chicago, University of Chicago Press.

Kacef, Osvaldo and Rafael López-Monti (2010), "Latin América, from boom to crisis: macroeconomic policy challenges", cepal Review, No. 100 (LC/G.2442-P), Santiago, Chile.

Kindleberger, Charles P. and Robert Z. Aliber (2009), Da euforia ao pânico: uma história das crises financeiras, São Paulo, Editora Gente.

Krugman, Paul R. (2009), A crise de 2008 e a economia da depressão, Rio de Janeiro, Elsevier.

Lopes, Francisco L. (2009), "A dimensão da crise", Como reagir à crise? Políticas econômicas para o Brasil, Edmar L. Bacha and Ilan Goldfajn (orgs.), Rio de Janeiro, Imago.

Mohan, Rakesh (2009), "Global Financial Crisis: Causes, Impact, Policy Responses and Lessons", presentation at the Annual India Business Forum Conference, London, London Business School.

Rogoff, Kenneth S. and Carmem M. Reinhart (2010), Oito séculos de delírios financeiros: desta vez é diferente, Rio de Janeiro, Elsevier.
Rose, Andrew K. and Mark M. Spiegel (2009), "Cross-country causes and consequences of the 2008 crisis: early warning", nber Working Paper, No. 15357, Cambridge, Massachusetts, National Bureau Economic Research.

Roubini, Nouriel and Stephen Mihm (2010), A economia das crises: um curso-relâmpago sobre o futuro do sistema financeiro internacional, Rio de Janeiro, Intrínseca.

Taylor, John B. (2009), "The financial crisis and the policy responses: an empirical analysis of what went wrong", nber Working Paper, No. 14631, Cambridge, Massachusetts, National Bureau Economic Research

Torres Filho, Ernani Teixeira (2008), "Entendendo a crise do subprime", Visão do desenvolvimento, No. 44, Rio de Janeiro, Brazilian Development Bank.

Torres Filho, Ernani Teixeira and Gilberto Rodrigues Borça Júnior (2008), "A crise do subprime ainda não acabou", Visão do desenvolvimento, No. 50, Rio de Janeiro, Brazilian Development Bank.

TCU (Tribunal de Contas da União) (2009), "Relatório das contas do governo. Exercício de 2009", [online] portal2.tcu.gov.br. 